\title{
Bioethical language and its dialects and idiolects
}

\author{
O idioma bioético, seus dialetos e idioletos
}

Volnei Garrafa 1,2

Debora Diniz 1,2

Dirce Bellez Guilhem 1,2

\footnotetext{
1 Faculdade de Ciências da Saúde, Universidade de Brasília.

C. P. 04367, Brasília D. F. 70910-970, Brasil.

2 Centro de Estudos Avançados Multidisciplinares, Núcleo de Estudos e Pesquisas em Bioética, Universi dade de Brasília. C. P. 04367, Brasília, D. F. 70919-970, Brasil.
}

\begin{abstract}
In their search for answers to the relevant theoretical questions on importing knowledge in practical ethics, the authors take an instrumental approach to metaphor. This figure of language al lows one to compare language and linguistic variants to bioethics and knowledge. As defined by the dictionary, an 'idiom' is the official language of a nation, a 'dial ect' is a regional variant of an idiom, and an 'idiolect' is an individual variant of a dialect. The bioethical idiom is thus seen as a linguistic set constituting a 'bi oethical nation'. Since it is situated above particuIar dialects, it exercises more than a regulatory role over the discipline. In this article, in order to focus on the process of transmission of knowl edge in bi oethics, the authors chose Diego Gracia's work as a paradigmatic reference to the question on the transcul turation of dialects and the re lations in bioethics which are considered 'peripheral' or 'central'. Although this researcher found the key question pointing to the core of the problem of importing dial ects, he is still searching for a proper answer to the cultural/bi oethical context/contradiction.
\end{abstract}

Key words Bioethics; Language; Epistemology

Resumo Na procura de respostas à questão teórica relativa à importação de conheci mento em ética prática, os autores utilizam, de forma instrumental, a metáfora. Essa figura de linguagem permi te que se compare o idioma e suas variantes lingüísticas com a bi oética e seus saberes. Segundo o registro dicionarizado, o idioma é a língua oficial de uma nação, o dial eto é uma variante regional de um idioma e o idiol eto é uma variante individual de um dial eto. O idi oma bi oético é entendido, então, como um conjunto lingüístico que constitui a 'nação bi oética' e que, por estar acima dos dial etos particulares, exerce um papel sobre-regulador na disciplina. Os dialetos correspondem às vári as correntes ou teorias existentes e realizam a ponte entre o i dioma ea prática. Os i diol etos são frutos de tentativas críticas de adaptação de di al etos específicos a contextos sócio-culturais diferentes daquel es onde os dial etos surgi ram. Neste arti go, com o objetivo de apontar para o processo de transmi ssão do conheci mento em bioética, os autores escol heram a obra do bi oeticista Diego Gracia como referência paradigmática para a questão da transculturação de dial etos e das rel ações entre as bi oéti cas consi deradas centrais e periféricas.

Palavras-chave Bioética; Linguagem; Epistemologia 


\section{Introduction}

Some authors believe bioethics to be a cultural movement which began in the 1960s as a consequence of the social effervescence characterizing the time. Others consider it a new paradigm for ethical studies which revolutionized traditional medical ethics inspired by Hippocrates. In the midst of these debates on the status of bioethics, the controversy referring to emerging studies as to whether bioethics was a new science is now commonly accepted in the reflections of those concerned with its epistemology. Although this article is involved in a larger epistemological study on the subject, it is not directly concerned with the above point. At this stage we are not dealing with studies on the status of bioethics, despite their importance.

The specific point of departure for this article's analytical study is the conclusion that current studies on bioethics involve many researchers from all over the world. There are already a number of national societies (in Brazil we have associations, specialized periodicals, university institutions, and public agencies), in addition to the Latin American Bioethics Program and the International Association of Bioethics, all providing links between the socalled bioethicists. Studies to identify such researchers, their academic and professional backgrounds and lines of research, and institutional affiliations would be extremely valuable for an enhanced understanding of the field of studies on bioethics. Thus, in the midst of relative ignorance as to 'bioethical biographies' and within the confines of an exploratory case study, this article is intended to analyze the field's transculturation process, drawing on the work of Spaniard Diego Gracia, a well-known bioethicist in intellectual circles (Gracia, 1989; 1990a; 1990b; 1990c; 1993; 1995a; 1995b; 1995c; 1996a; 1996b). Gracia's work will be the reference for this ethnographic exercise on bioethical thinking. However, before presenting the reasons for choosing this author as the mediator for our analysis, we will outline our article and its objectives.

We begin with a metaphor between the arrangement of language and the production and make-up of knowledge in bioethics. The use of metaphor is merely a tool that we employ basically for its heuristic properties. We use the concepts of 'central' and 'peripheral' as indicators of the way by which knowledge is established and divulged in an attempt to identify the set of relations in bioethical knowledge in different countries (Garrafa et al., 1997).
With this conceptual picture in mind, we introduce Diego Gracia's writings as a paradigm for what we consider a highly relevant theoretical issue: the importing of knowledge into practical ethics.

\section{The language metaphor}

The use of some linguistic trope is always welcome as an aid in the argument. Herein we make use of a well-known and widely used figure of language, metaphor, by which one can make unconventional use of words and their meanings as long as there are underlying similarities between their proper and figurative meanings. Likewise, for structuring the makeup of knowledge in bioethics, we will use metaphor with language and its variants dialect and idiolect (this use of language as a metaphor for the intellectual production of a given discipline has already been used by researchers in other areas of knowledge; see Oliveira, 1988, 1995). Ordering language and its branches, dialects and idiolects, is the framework within which we attempt to map out the current state-of-the-art in bioethics. We now proceed to explain metaphor in more detail.

According to the dictionary, use of the term 'Ianguage' refers to the official language of a nation, 'dialect' to a regional or social variation thereof, and 'idiolect' to an individual variation of a dialect. We thus consider bioethical Ianguage the linguistic set allowing for the constitution of the 'bioethical nation', in this case understood as the continental and world spheres linking up researchers. This common language allows a New Zealand bioethicist to exchange ideas with a Chinese bioethicist, and s/ he in turn with a North American, despite their particular dialects. The language plays a regulative role over the discipline above and beyond specific dialects. And this is what allows us to define bioethics. As a matter of fact, there is no specific language pertaining to 'bioethics' itself, and the very word 'bioethics' has a gentile and stategic meaning because was able to verify general diverse aspects related to a great issue. In this sense bioethicicts are able to speak to each other because of a common issue recognized as significant.

The dialects, in their turn, as social variations of the language, correspond to various strains or existing theories on bioethics. These are some examples of dialects in bioethics: principlism, casuism, contextualism, humanism, among others. Dialect, in that it suggests singularity, is best perceived through compari- 
son. It is through this that particularities of principlism and humanism, for example, are accentuated, or in other words, that its dialect variations are highlighted. The study of the dialects has to be conducted while bearing in mind that the role of these dialects is exactly to make possible the bridge between language and practice.

Finally, the idiolect is an individual variation of a specific dialect. In spite of some linguistic studies to counter that the idiolect is shared by more than an individual, for the purpose of this article, or rather, for the metaphorical use we accomplish between a language and the bioethics, it is irrelevant whether the idiolect is individual or shared by a restricted group. The analysis of these idiolects highlights the extreme importance, because they are a result of the critical attempts of adaptation of specific dialects to socio-cultural contexts different from those from which they originated.

By this means, after the mapping out the organization of the bioethical language, we will go on to why we chose Diego Gracia's works for the case study.

\section{Why Diego Gracia?}

We chose Diego Gracia's writings as ethnographic reference for the reflections we will outline below for the following reasons:

Firstly, because he is a peripheral bioethicist. We understand peripherical bioethics as developed from peripherical countries, i.e., countries where bioethics happened later on and where the studies are characterised by the importing of bioethical theories from central countries, those from where the bioethics originated and has been consolidated. It is important to bear in mind that the central and peripheral denominations should always be seen as temporary (it is possible, for example, that a country initially peripheral becomes central as the years go by). Thus, a country such as Japan is peripheral related to the structuring and production of bioethical studies, as are Brazil, Canada or Korea, to mention a few. On the other hand, a unanimously considered central country would be the United States of America, specifically for the purpose of this article, as Gracia considers that “....bi oethics has been and still is basically a United States movement..." (Gracia,1996b:593). It is also worth remembering that central and peripheral denominations only make sense when in a mutual relationship and that its use is to allow for one to draw a sociometry of the intellectual transaction in bioethics between the countries.

Secondly, this reason is a result of the characteristics of its intellectual production. The author has published a number of works, not only in periodicals in peripheral countries, but also in periodicals in central ones, as well as presenting certain original arguments, a few of which will be the core of this article. In fact, we will analyse Gracia's intellectual production since his return from the United States, in 1986, where bioethics was introduced to him (Spinsanti, 1995:100). His first publication that marks this turnabout in respect of bioethics, the book Fundamentos de Bioética, came out three years later (Gracia, 1989). The author has a series of other publications on the subject of medical ethics prior to this 'rite of passage' into bioethics. These were set aside from this analysis.

Finally, because Gracia has an important administering role in the diffusion of bioethics. He was responsible for the structuring and initial co-ordination of the first masters degree in bioethics in Latin America, based in Chile, under the support of the Pan-American Health Organization PAHO/WHO.

The principlism as dialect

As head-lecturer of the cathedra on the History of Medicine, at the University of Complutense in Madrid, and follower of Pedro Laín Entralgo, considered an important representative of the Spanish medical humanism (Viafora, 1990; Spinsanti, 1995) Diego Gracia was a student of the history and philosophy of medicine when he first came into contact with bioethics during his visit to the United States in 1986. Back in Spain, and influenced by the North American bioethical thought, Gracia dedicated himself to reflecting on the hegemonic dialect then reigning in the USA: the principlism - in Hard Times, Hard Choices: Founding Bioethi cs Today from wich we quote: "principles-oriented bi oethics has been the true bioethical orthodoxy, and that today, in spite of its critics, it remains the dominant paradigm..." (Gracia, 1995a:194). However, the peripheral practice of the acritical transculturation of the principlist dialect provoked an unease in Gracia that ended by assuming the re-creation theme as the reason for his research. He stated in The Intellectual Basis of Bioethics in Southern European Countries: “... because modern bioethics made its appearance in the Anglo-American culture, Europeans in general, and Mediterraneans in particular, have attempted not simply to 'im- 
port' or 'translate' bioethics, but rather to 'recreate' or 'remake' the discipline according to thei $r$ own cultural and ethical traditions..." (Gracia, 1993:98).

The idea of an adaptation of the principlist model (that based on the four following principles: autonomy, non-maleficence, beneficence, and justice) to a Spanish reality - in fact Gracia does not refer to Spain in particular, he either speaks about the Latin, or the Mediterranean traditions - has become the key factor in his writings. To some extent this emphasises his adhesion to the dialect of principles. However, although not provoking any significant changes in the bioethical hegemonic dialect, Gracia has managed to imprint some original casting on the initial structure, such as, for example, in his proposal to transform the four principles into two moral bases. Such an idea was developed, mainly, in Hard Times, Hard Choi ces: Founding Bi oethics Today: that would become the private duties, of a theological basis, made up of the beneficence and the autonomy and the public duties, of deontological basis, made up of non-maleficence and justice (Gracia, 1995a:196).

To have an account of the meaning of Gracia's theoretical step - of organizing the four principles into two moral references - it is necessary to be aware of a characteristic typical of the peripheral bioethicists. Generally, these last misunderstand dialect, especially the dialect of principles, as being the bioethics language itself. Sentences such as those found below are recurrent in the majority of peripheral writings: "...the first thing I must say is that bioethics is perceived by Mediterraneans as something foreign, or at least as something different from the Mediterranean ethical tradition..."(Gracia, 1993:98). In such a case, it is not necessarily the bioethics that is perceived as something strange by the Mediterranean, but the dialect of principles, and, specifically, its emphasis on the principle of autonomy that, according to Gracia, does not have the same weight for those countries of south-eastern Europe as for the Anglo-Saxon ones. Nonetheless, despite the author also falling into the bad habit that makes a bioethic dialect to be understood as its own language, the search for reinterpretation of a specific dialect, no doubt, represents a great advance. And it is at this stage of reinterpretation we understand the author has created an idiolect. It is worth highlighting that the peripheral rarely manage to achieve this. The great majority among the peripheral group is busy replicating a particular dialect (for example, in the Brazilian or even South
American case, the preferable dialect is that of principles).

It is important to point out that, although Gracia's works constitutes an idiolect in our opinion, this does not mean that, in the future, it will necessarily evolve towards a particular dialect. There are no obligatory evolving processes between idiolect and dialect. The author made an important and original step, but only with the passing years and the propagation of his writings will it be possible to evaluate whether his suggestions about the dialect of the principles will provoke definitive ruptures, either creating or not another dialect. Thus, further to not having a mechanical sequence from idiolect to dialect, being more a continuous backwards-forwards movement, we remember that the process of importing dialects is not an exclusive characteristic of a discipline, as for example the bioethics. On the contrary, it is present in many sciences (Oliveira, 1988; 1995). In bioethics, nevertheless, the movement is strengthened by the importing tradition that characterises medicine in peripheral countries. In fact, by a technological and scientific dependence, we import the technique from central countries to an extent we consider that the greater science's credibility is, the greater its openness to technical discoveries in central countries. Notwithstanding this, the importing of a medical technique, for example, implies, to a certain extent, the importing of ethics that inspired its discovery, or, at least, the ethics of its application. For the peripheral medical exercise, the silent association between technique and ethics is still partly unknown, which is a reason for importing so freely the first (Diniz, 1997). Such symbiosis between technique and ethics prevents the professional from accordingly differentiating between each category of the binomio. It is even more delicate when it refers to fields of medical knowledge where the technique itself is non-existent, only the ethics remaining, as in the case of bioethics. Even in these situations, the bad habit of importing is maintained: in the world of ethics one acts as if a technique has been imported.

\section{Contrastive idiolects and identity}

Diego Gracia's works are, then, a result of this continuous movement between the importing of the dialect of principles and the idiolect construction that, if we followed some of the author's ideas, could be called 'Latin idiolect'. As we consider such an idea of Latinity defended 
by Gracia as needing greater depth, we would then nominate this dialect of principles variation 'contrastive dialect'. We will explain the reason for this.

The principlism is, among the bioethical dialects, the one that gains most sympathy from the greatest number of bioethicists. Its convincing power is sustained not only by its theoretical basis, but mainly its instrumental efficiency. Or, as considered by Gracia, the four principles are as a knot that puts together all the values of the moral world: “...these are something like nucleus of confluence of all the universe of values. Not that there are not any other values, in fact what happens is that they concentrated around these four axis or points. In other words, all value questions can be ordered around these four principles..."(Gracia, 1995c:40).

The principles function, then, as 'moral tools' that allow for the organization of the apparently chaotic world of values. The author makes use of such instrumental power of the principialist dialect, but indicates the differences between the ethical traditions of the Anglo-Saxon and the Latin countries. He states: “... I have addressed the ethical peculiarities of the Southern European Countries. We feel we are different, ethically different, from other civilizations and cultures... We must accept differences, ethical differences..." (Gracia, 1993: 106).“... In the present paper I propose to study thehistorical setting of Latin American bi oethics. This is necessary because the culture of these peoples stem not from the Anglo-Saxon but from the Latin and Mediterranean tradition, from which it has derived highly specific characteristics..."(Gracia, 1996b:594).

In spite of Gracia referring in his analysis to the concept of culture - for us, the only efficient path in the measuring of the differences between the peoples -, the reference used for the contrast between the 'Anglo-Saxon peoples' and the 'Latin peoples' was not the cultural diversity itself, but what he called the 'different ethical traditions' (inappropriately the author refers to the concept of culture or even the concept of people; both are argumentative ways used for comparison, however these lack more secure ethnographic references). In other words, in contrast with the individualist inheritance of the Anglo-Saxon in which values such as autonomy or tolerance would be traditional, the author suggests that the Latin tradition, heir of the Greek philosophy, would strengthen values such as virtue, intolerance or friendship (Gracia, 1993). The argument of the ethical difference, in the name of the different philosoph- ical traditions, was the way found by the author to highlight the socio-cultural particularities of each civilization. In the face of the weakness of this argument - as it is difficult to understand what the author means by concepts such as 'paternalism', 'intolerance of the Latin peoples' or for where the philosophical tradition may be the cultural index of a civilization - it is interesting to go through Gracia's intentions by counteracting the two above cited philosophical traditions.

The extent to which the bioethics dialect transculturation causes bad feeling is visible in the author's intellectual production. That is why, in the search for the 'adaptation' of the dialect of principles to the Spanish reality, Gracia identifies the differences between culture that has inspired the dialect creation and the culture to which the imported dialect is destined (it is worth strengthening here the definition of dialect as being 'a social variant of the Ianguage'). At this stage of classical cultural shock between culture-reference of the dialect and the importing-culture, is that Gracia seeks the 'traits' that mark each civilization's particularities (see Geertz for development of the idea of culture used here, in A Intepretação das Culturas, 1989). From these the allusions of the Latin peoples as intolerant, affective or oriented by virtue (Gracia, 1993, 1995a, 1995b). In reality, these 'cultural traits' only make sense when put against each other, the latter being considered strange to the group in question. For example: a reference to the paternalism as a cultural trace of the Latin peoples only makes sense when opposed to the idea of autonomy, as being characteristic of the Anglo-Saxons. In other words, the transculturation difficulty of the dialect of principles that took Gracia to the reflection over cultural identities. By this means, from behind the make-up of an idiolect, Gracia's set of works suggests a process of identity demarcation. Like the idiolect, we could call this contrastive identity, once it implies in the affirmation of us, the Latin, facing the others, the Anglo-Saxons. The identity suggested by Gracia as representative of the Latin peoples is not affirmed in isolation. The Latin identity derives negatively from the 'cultural traits' considered Anglo-Saxon. On this it is worth noting the following text:"...I would like to conclude this presentation (sic) analysing a concrete context, that of the Latin countries or Latin culture. Ethics was born twenty-five centuries ago in a Mediterranean country, Greece. And the ethics created by Socrates, Plato and Aristotlewas not principle-oriented but virtue-oriented. In the past, this has been the profound ethical belief of 
our societies and it continues to be so now. Latin people are profoundly uncomfortable with rights and principles...Latin countries have traditionally been very intolerant...This is perhaps our most important difference with other cultures..." (Gracia, 1995a:206).

In this process of the make-up of contrastive identity, or rather, in the search for 'cultural traits' which justify the difference and the impossibility of acritical importing of the principles' dialect, Gracia comes up against some enormous obstacles, especially when justifying the similarity between such different peoples as the Spanish, French, Chileans and the Brazilians, for example (in spite of them all being 'Latin'). In his haste at not having a reference group which represents the above stated latinity, the author appeals to history as a uniting mechanism for the identities (at other times, he appeals, rather unclearly, to geography - countries in Latin America - or to the spoken language, in this case 'countries of the Spanish language'). This is a cultural strategy which finds an echo in certain ethnographic accounts about some ethnic minorities in danger of extinction. One example is an account by Oliveira in a classic work about the process of the make-up of identities in fragmented groups; he says: “...the situation of the Kinikinau (Indians) is a limited case, in which a set of individuals, with no ethnic reference group in existence, appeals to history and holds itself up as an ethnic category...."(Oliveira, 1976:13). Just like the Kinikinau, Gracia, in The Historical Setting of Latin American Bioethics (1996b), he leans on the mythical time of Spanish colonization in some Latin American countries to justify the similarity of identities. He states, in a quote already referred to in this article: “...In the present paper I propose to study the historical setting of Latin American bi oethics. This is necessary because the culture of these peoples stems not from the Anglo-Saxon but from a Latin and Mediterranean tradition, from which it has derived highly specific characteristi cs..." (Gracia, 1996b:594).

Or, in other words, just like the Kinikinau Indians, Gracia tries to find 'cultural traits' which would trace out differences between the Latin and Anglo-Saxon tradition societies as the sole way of attaining a dialect suitable for each people. However, only referring to Spain or Chile (countries with which the author would have more cultural ties) would not have the same arguing power as talking about Latinate (or, in his words, in 'Latin culture moral life') in contrast to the individualistic Anglo-Saxon tradition. Indeed, rather than this being a cultural fallacy, as was pointed out above, we believe it was the author's deliberate attitude, as was adopted by the Kinikinau. Gracia had already perceived that in order to have any make-up of a dialect in bioethics, or even for a dialect variation to be consistent, it is necessary to set out a solid demarcation of the difference between peoples. This is a way of softening, for example, the difficulties of a transculturation of dialects. And in the absence of a group which can give it identity, it makes up its own from remote and mythical pasts, as the author did when he points to the cultural meeting on the occasion of the colonization of part of Latin America by Spain. In actual fact, then, the Latin becomes a creation of Gracia's writings, and ends up coming more from common sense that accurate ethnographic descriptions (on this process of the creation of the 'other' through cultural stereotypes, it is worth reading Said's O Orientalismo: O Oriente como Invenção do Oci dente; 1990).

Having said this, we would not be afraid to affirm that Gracia's work has taken on the task of trying to demarcate, or even to create, the Latin identity. The strategy of cultural contrast, used to unveil which traits in each culture would make up this identity, was the mechanism used to justify the values selected by each people. This part of Gracia's work is at the same time the most interesting and the weakest point in his writings. And we will now turn to a discussion of this.

\section{Beyond Diego Gracia}

Gracia believes that the theme of re-creation of bioethic dialects is not the exclusivelly task of his writings. In Orientamenti eTendenze della Bioetica nell'Area Linguistica Spagnola he states: “...Well, my thesis is that this confrontation is not entirely exact, since in their purely technical scientific aspects thenew things which reach the other side of the Atlantic can bemade equal to, in the face of a simple 'translation'. This is in contrast with the social and human aspects, as they are precisely ethical, a mere translation is not enough and occurs in the complex process of 're-creation'. This, for me, is the challenge of the present European bi oethics: see if it is ableto recreate problems particular to Bioethics, in the light of its traditions and its own culture..." (Gracia, 1990c:271).

Re-creation should be, according to the author, the peripheral bioethicists' favourite theme. By re-creation, one can understand both the attempt to demarcate identities as much as the search for dialect variations with a 
view to making up a future dialect should be kept in mind. This idea of re-creation or at least the discomfort as to acritical importing of dialects is the beauty of Gracia's writings. The weakness, however, lies in the way the task was carried out. And this comes about for two reasons.

Let us begin with the first. Gracia's key-question, present in all the analysed articles, is satisfactorily summed up in the following extract, taken from The Intellectual Basis of Bi oethics in Southern European Countries: “... How is bi oethics perceived in different places and by different cultures? Are the problems similar? Perhaps not at all. And the solutions, are they also similar? Certainly not..."(Gracia, 1993: 113).

With these questions, the author points both to the core of the problem of the transculturation of dialects as much as to the set of relations between peripheral and central bioethics. However, the possibility of answering these questions eludes him, probably for the same reason as that which led him to ask it: his adhesion to a principlist theory. We will explain further: it was the hasty and hegemonic use of the principlist theory by peripheral bioethicists which led Gracia to reflect on the limits of importing and about the difficulties of the transculturation of dialects, once the latter, when acting as a bridge between idiom and practice, end up by referring to specific sociocultural contexts (Kleinman, 1995). This statement about the cultural limits of the principlist dialect worried the author, briefly summed up in the questions quoted in the above extract. However, the development of Gracia's critical ideas as to the principles' dialect was to some extent softened by his own commitment to the theory. Or in other words, his analysis was silenced by its own starting point: the author's link to the principlist dialect. The review implied a distancing, at least momentarily, from the dialect, which is missing from the author's writings.

The second reason which made much awaited critical disclosure impossible in the work, in the face of the theory of the four principles, is the fact that asking the question 'How is bioethics perceived in different places and by different cultures?' would demand that the author make particular analyses about each culture. For example: for a scholar of euthanasia in Peru and a sympathiser of the principialist dialect, the first necessary step for the importing of the dialect to be effective would be to have an ethnographic drawing of the Peruvian culture, both of national society and ethnic groups, in relation to the human body, death, religion, family, in fact any important facet of the native culture which relates to the end of life. Only in this way, one could evaluate the limits and successes of each principle. To carry out this type of study, it is not enough to talk about 'ethical traditions' or 'philosophical inheritance' as representative elements of the differences or cultural traits which identify and differentiate peoples. It is necessary to turn to careful studies about the cultural beliefs of each people (and about the importance of cultural studies towards bioethics, refer to the article Transporting Values by Technology Transfer of Castro on the conflict of values which happened in the Philippines, generated by the practice of organ transplant and its reflections on the local culture (Castro, 1997).

These were the two points in Gracia's work - his commitment to the principlist theory and the absence of careful ethnographic studies which prevented him from making headway in a critical sense, after the question quoted above. The author, in spite of formulating the correct question - which addresses one of our primordial preoccupations: the process of transculturation of bioethical dialects - could not answer it because of the relation of domination of the principialist theory which overrides his work. We are certain that one of the ways which would allow Gracia to go forward in his work, above the process of transculturation of knowledge in bioethics, will be the study of the cultural particularities of each people. Only if he is able to fill in this gap in the work will the author be able to reach one of the objectives of bioethics, which is the respect of cultural pluralism and human dignity. 


\section{References}

CASTRO, L. D., 1997. Transporting values by technology transfer. Bioethics, 11:193-205.

DINIZ, D.,1997. Técnica, Ética e Cultura. Projeto de Tese de Doutorado, Brasília: Departamento de Antropologia, Universidade de Brasília (mimeo).

GARRAFA, V.; OSELKA, G. \& DINIZ, D., 1997. Saúde pública, bioética e eqüidade. Bioética, 5: 27-33.

GEERTZ, C., 1989. A Interpretação das Culturas. Rio de Janeiro: Guanabara.

GRACIA, D., 1989. Fundamentos de Bioética. Madrid: Eudema.

GRACIA, D., 1990a. Que es un sistema justo de servicios de salud? Principios para la asignación de recursos escasos. In: Bioetica: Temas y Perspectivas (Organización Panamericana de la Salud, ed.), pp. 187-201, Washington: Organización Panamericana de la Salud.

GRACIA, D., 1990b. La bioetica medica. In: Bioetica: Temas y Perspectivas (Organización Panamericana de la Salud, ed.), pp. 3-7, Washington: Organización Panamericana de la Salud.

GRACIA, D., 1990c. Orientamenti e tendenze della bioetica nell'area linguistica spagnola. In: Vent'anni di Bioetica (C. Viafora, ed.), pp. 269-299, Padova: Fondazione Lanza.

GRACIA, D., 1993. The intellectual basis of bioethics in Southern European countries. Bioethics, 7:97107.

GRACIA, D., 1995a. Hard times, hard choices: founding bioethics today. Bioethics, 9:192-206.
GRACIA, D., 1995b. Medical ethics: history of Europe - Southern Europe. In: Encycl opedia of Bioethics (T. W. Reich, ed.), pp. 1556-1563, vol. 3, New York: Simon and Schuster Macmillan.

GRACIA, D., 1995c. El que y el porque de la bioetica. Cuadernos del Programa Regional de Bioetica, 1: 36-53.

GRACIA, D., 1996a. Ética de la calidad de vida. Cuadernos del Programa Regional de Bioetica, 2:4359

GRACIA, D., 1996b. The historical setting of Latin American bioethics. Journal of Medicineand Philosophy, 21:593-609.

KLEINMAN, A., 1995. Writing at the Margin. Berkeley: California Press.

OLIVEIRA, R. C., 1976. Identi dade Étnica, Identificação e Manipulação. São Paulo: Pioneira.

OLIVEIRA, R. C., 1988. Por uma Etnografia das Antropologias Periféricas. Rio de Janeiro: Paz eTerra.

OLIVEIRA, R. C., 1995. Notas Sobre uma Estilística da Antropologia. Campinas: Unicamp.

SAID, E., 1990. Oriental ismo: O Oriente como Invenção do Ocidente. São Paulo: Companhia das Letras.

SPINSANTI, S., 1995. Diego Gracia: dall 'olfatto morale' alla ricerca di un metodo. In: La Bioetica: Biografie per una Disciplina (S. Spinsanti, ed.), pp. 100-110, Milano: Franco Angeli.

VIAFORA, C., 1990. Lo studioso. In: Vent'anni di Bioetica (C. Viafora, ed.), pp. 252-254, Padova: Fondazione Lanza. 